AFCRL -173

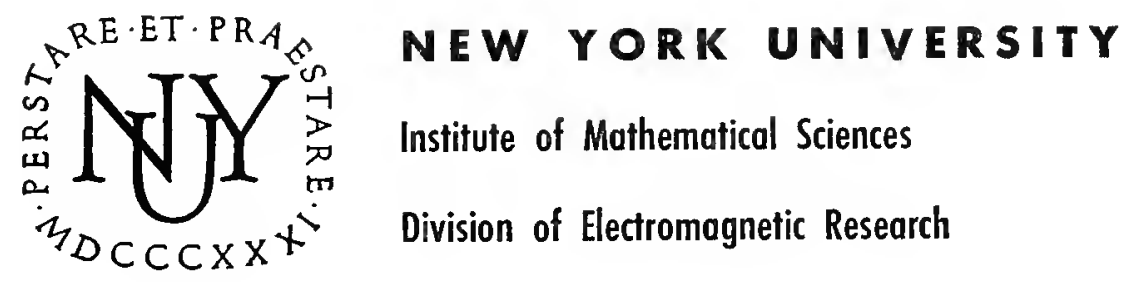

RESEARCH REPORT No. EM-169

\title{
A Convergent 'Farfield' Expansion for Two-Dimensional Radiation Functions
}

S. N. KARP

Contract No. AF 19160415238

APRIL, 1961 

NEW YORK UNIVERSITY

Institute of Mathematical Sciences

Division of Electromagnetic Research

Research Report No. EM-169

A. CONVERGENT 'FARFIELD' EXPANSION FOR TWO-DIMENSIONAL

RADIATION FUNCTIONS

S. N. Karp

Jy. $/$ ars

S. N. Karp

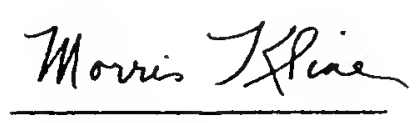

Morris Kline

Project Director

The research reported in this document has been sponsored by the Electronics Research Directorate of the Air Force Cambridge Research Laboratories, Office of Aerospace Research (USAF) Bedford, Mass. under Contract No. AF 19(604)5238. 
Requests for additional copies by agencies of the Department of Defense, their contractors, and other Govermment agencies should be directed to the:

ARMED SERVICES TTECHNICAI INFORMATION AGENCY

DOCUMENTS SERVICE CENTER

ARLINGTON HALI, STATION

ARLINGTON 12, VIRGINIA

Department of Defense contractors must be established for ASTIA services or have their 'need-to-know' certified by the cognizant military agency of their project or contract. All other persons and organizations should apply to the:

U.S. DEPARTMENT OF COMMERCE

OFFICE OF IECENICAI, SERVICES

WASHINGTON 25, D.C. 


\section{Abstract}

Radiative solutions of the three-dimensional Helmholtz equation $\Delta u+k^{2} u=0$ are known to be representable in the form $u=r^{-1} \exp (i k r) f(1 / r, \theta, \phi)$ with $f(1 / r, \theta, \phi)=f_{0}(\theta)+\sum_{n=1}^{\infty} f_{n}(\theta, 0) r^{-n}$, where the series is both asymptotic and convergent. In fact $f(I / r, \theta, \phi)$ is known to be an analytic function of $I / r$ for $|r|>$ a provided alI the singularities of u are contained in the sphere of radius a. On the other hand, in two dimensions, the corresponding farfield expansion

$$
u=r^{-1 / 2} e^{i k r}\left[f_{0}(\theta)+\sum_{n=1}^{\infty} f_{n}(\theta) r^{-n}\right]
$$

is asymptotic, but is not convergent. We remedy this defect by showing that any radiative solution of the two-dimensional Helmholtz equations can be written in the form $u=H_{0}^{(1)}(\mathrm{kr}) \mathrm{E}\left(\frac{1}{r}, \theta\right)+H_{1}^{(I)}(\mathrm{kr}) O\left(\frac{I}{r}, \theta\right)$, where the functions $E$ and $O$ are analytic functions of $\frac{I}{r}$, for $|r|>a$, and are of course expressible as convergent power serles in $\frac{I}{r}$. Here a is the radius of the smallest circle contalning the singularities of u. Furthermore, we show how to deduce $E(0, \theta)$ and $0(0, \theta)$ from the customary farfield datum, namely $f_{0}(\theta)$, and vice versa.

The convergence of the new formula may be useful in converting indoor measurements into farfieid patterns. 
Table of Contents

$\underline{\text { Page }}$

I. INTRODUCIION

II. ANALYSIS 5

III. DETERMINATION OF THE COEFFICIENTS 8

BIBLIOGRAPHY 12 


\section{S. I. Karp}

A CONVERGND 'FAREIELD' EYPANSION FOR TWO-DINENSIONAL RADIATION HUNCTIONS

page 5, line 1 - Replace $\mathrm{H}_{\mathrm{n}}(\mathrm{kn})$ with $\mathrm{H}_{\mathrm{n}}(\mathrm{kr})$

page 5, equation (7) - Replace $n>a$, with $r>a$ :

page 5, Iine immediately folloring equation (8) - Replace $r \geq b>0$, with $r \geq b>a>0$

page 6, equation (14) - Equation should read:

(14) $E(I / k b$ expia, $\theta)=\sum_{n=0}^{\infty} \frac{u_{n}(b) \cos \left(n \theta+\gamma_{n}\right)\left(\frac{n}{n !}\right)\left(\frac{k b}{2}\right)^{n} e^{i n a}}{\frac{n}{n !}\left(\frac{r b}{2} \exp i a\right)^{n} H_{n}(k b)} \cdot\left[p_{n}\left(1 / k b e^{i a}\right)\right]$

page 7 , equation (16)- Replace $=J_{-1}\left(k b c^{i a}\right)$ with $=J_{-1}\left(\right.$ kbe $\left.{ }^{i a}\right)$

$$
\text { wing replace }=J_{0}\left(k b c^{i \alpha}\right) \text { with }=J_{0}\left(k b e^{i \alpha}\right)
$$





\section{INPRODUCTION}

It is a known property $[1]$ of the Helmholtz equation, $\nabla^{2} u+k^{2} u=0$, that if a solution $u(x, y, z)$ obeys the Sommerfeld radiation condition and is regular in the exterior of a sphere of radius $a$, then it can be expanded in the form

$$
u=\frac{e^{i k r}}{r} \sum_{n=0}^{\infty} \frac{f_{n}(\theta, \phi)}{r^{n}}: r>a,
$$

where $r, \theta, \phi$ are polar coordinates. The series is actually convergent, and represents an analytic function of $(1 / r)$. The functions $f_{n}$ can be obtained recursively $[2]$ if the complex radiation pattern $f_{0}(\theta, \phi)$ is given.

On the other hand, $\vec{a}$ corresponding theorem in two dimensions is unknown. To be sure, an expansion analogous to that of (1) may be constructed [3] in the form

$$
u(x, y) \sim \sqrt{\frac{2}{\pi k r}} e^{1\left(k r-\frac{\pi}{4}\right)} \sum_{n=0}^{\infty} \frac{f_{n}(\theta)}{r^{n}}: r>a .
$$

But the example of the Hankel function $\mathrm{H}_{0}^{(1)}(\mathrm{kr})$, which is an exact solution of the two-dimensional equation, shows that a series of type (2) diverges. An attempt to repalr this defect by assuming

$$
u \sim H_{0}^{(l)}(k r) \sum_{0}^{\infty} \frac{g_{n}(\theta)}{r^{n}}: r>a,
$$


must also fail, since the wave function $\mathrm{H}_{I}^{(I)}(\mathrm{kr}) \exp (i \theta)$ cannot be so expressed. Thus, the two-dimensional theory lags behind the three-dimensional theory, at present. The purpose of this paper is to remedy this defect.

The principal result demonstrated below is the following:

Theorem I: Let $u(x, y)=\tilde{u}(r, \theta)$ be an outgolng wave function regular for $r>a>0$. Then there exists a convergent expansion, valid for $r>a$, in the form

$$
u=H_{0}^{(I)}(k r) \sum_{0}^{\infty} \frac{F_{n}(\theta)}{r^{n}}+H_{1}^{(I)}(k r) \sum_{0}^{\infty} \frac{G_{n}(\theta)}{r^{n}}
$$

Where the series converge uniformly and absolutely for $x \geq b>a$, and may be differentiated termwlse with respect to $r$ as often as desired.

We also prove

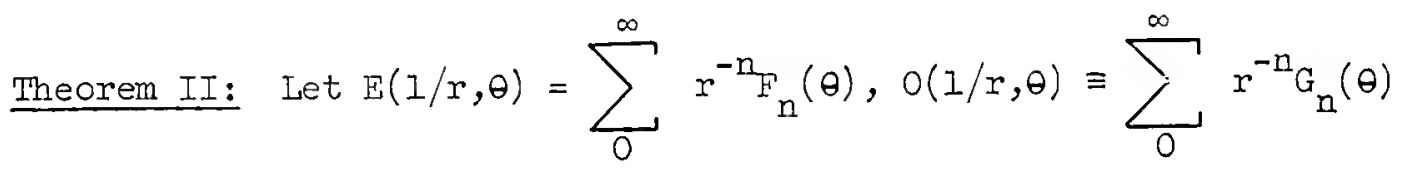
in the notation of Theorem I. Then E and $O$ are analytic functions of $(I / r)$, and are regular in the interior of the circle $|I / r| \leq 1 / b<1 / a$ in the complex $(I / r)$ plane, where $b$ is any positive number greater than a. We have

(4a) $\quad u=H_{0}^{(I)}(k r) \quad F_{1}(I / r, \theta)+H_{1}^{(I)}(k r) \cdot O(I / r, \theta)$. 
In addition, we show how the function $F_{0}(\theta)$ and $G_{0}(\theta)$ are related to $f_{0}(\theta)$, the complex radiation pattern. In fact, we prove Theorem III: The leading terms of $\mathrm{E}, \mathrm{O}$, are related to the complex radiation patterm by the formulae

(4b)

$$
\begin{aligned}
F_{0}(\theta) & =\frac{1}{2}\left[f_{0}(\theta)+f_{0}(\theta+\pi)\right] \\
-I G_{0}(\theta) & =\frac{1}{2}\left[f_{0}(\theta)-f_{0}(\theta+\pi)\right]
\end{aligned}
$$

Since the functions $F_{n}(\theta), G_{n}(\theta)$ may be obtained recursively, as explained later, in terms of $F_{0}$ and $G_{0}$, Theorem III makes it possible to construct the convergent expansion (4) in terms of the experimentally II saningful leading term, $f_{0}(\theta)$, of the asymptotic expansion ( 2 ).

It is natural to ask why the two-dimensional expansion theorem should turn out to have a more complicated form than does the three-dimensional one. The answer is that the situation in two dimensions is the more characteristic one. In fact, it can be shown that in three dimensions we have the convergent expansion

$$
u=\frac{e^{i k r}}{r} \sum_{0}^{\infty} \frac{\tilde{F}_{n}(\theta, \phi)}{r^{n}}-\left(\frac{e^{i k r}}{r}\right)
$$

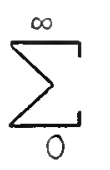
$\frac{G_{n}(\theta, \phi)}{r^{n}}$

This expansion is completely analogous to (4), since $[(\exp i k r) / r]$ and $H_{0}(k r)$ are the fundamental solutions in three- and two-dimensions and since $\mathrm{H}_{I}(\mathrm{I})(\mathrm{kr})$ is the derivative of $\mathrm{H}_{\mathrm{O}}(\mathrm{kr})$. The expansion (5) 
can also be rewritten in the form (1) due to the fact that $\left.[(\exp i k r) / r]^{\prime}=(\exp i k r)[i k-1 / r)\right]$.

The relationships discussed in the last paragraph can be made understandable when the respective methods of proof are explained. Consider first the proof of (1). That proof* is based on the expression of $u$ by means of Green's Theorem, using the fundamental function $((\exp i k R) / R)$ and its normal derivative on the sphere $r=a$, where $R$ is the distance between the field point $P(r, \theta, \phi)$ and the point $P\left(a, \theta_{0}, \phi_{0}\right)$. Here $P_{0}$ is a point on the sphere $r=a$. This yields an expression of $u$ in terms of integrals involving $u$ and its normal derivative on the boundary. The elementary functions of $\mathrm{R}$ which occur in the integrand can then be expanded in inverse powers of $r$, to prove the theorem. [For example, we have

$$
\left.\exp i k R / R=\left\{\frac{(\exp i k r)}{r}\right\} \frac{r \exp i k(R-r)}{R}\right\}
$$

and the second factor is an analytic function of $\frac{1}{r}$ in the neighborhood of infinity.] The proof of (1) thus depends on the elementary character of the exponential function. This method doesn't seem to be applicable in two dimensions. The method of proof we have employed in the present work is quite different. It is based on the fact that the function $u(x, y)$ can be written in the form

$$
u=\sum H_{n}(k r)\left(a_{n} \cos n b+b_{n} \sin n \theta\right),
$$

for $r>a$, and, in addition, on the well known fact that the recurrence ${ }^{*} \operatorname{cf} . \quad[1]$ 
formula for cylinder functions allows us to express $H_{n}(\mathrm{kn})$ as a linear combination of $H_{0}(\mathrm{kr})$ and $H_{I}(\mathrm{kr})$ with coefficients which are polynomials in $(1 / r)$. The polynomials are Lomel's polynomials [4]. We show below that the resulting expression, namely

(6)

$$
\begin{aligned}
u & =H_{0}(k r) \sum P_{n}\left(\frac{1}{k r}\right)\left(a_{n} \cos n \theta+b_{n} \sin n \theta\right) \\
& +H_{1}(k r) \sum Q_{n}\left(\frac{1}{k r}\right)\left(a_{n} \cos n+b_{n} \sin n \theta\right) ; r \geq b>a,
\end{aligned}
$$

can be rearranged so as to take the form given in (4).

\section{ANALYSIS}

Suppose

$$
\begin{aligned}
& \text { (7) } u_{x x}+u_{y y}+k^{2} u=0, \quad n>a, \quad k \text { real, } \\
& \text { (8) } \lim _{r \rightarrow \infty} \sqrt{r}\left(u_{r}-i k u\right)=0 .
\end{aligned}
$$

The function $u$ is analytic, for $r \geq b>0$, and hence we may write

$$
u=\sum_{n=0}^{\infty} \frac{H_{n}^{(l)}(k r)}{H_{n}^{(l)}(k b)}\left[u_{n}(b) \cos \left(n \theta+\gamma_{n}(b)\right], r \geq b>a>0,\right.
$$

$$
u(b \cos \theta, b \sin \theta) \equiv \tilde{u}(b, \theta)=\sum_{n=0}^{\infty} u_{n}(b) \cos \left(n \theta+\gamma_{n}\right),
$$


where the Fourier coefficients $u_{n}(b) \cos \gamma_{n}, u_{n}(b) \sin \gamma_{n}$ tend to zero more rapidly than any inverse power of $n$. On the other hand, we know that $[4]$

$$
H_{n}(k r)=H_{0}(k r) P_{n}\left(\frac{1}{k r}\right)+H_{1}(k r) Q_{n}\left(\frac{1}{k r}\right)
$$

where $P_{n}\left(\frac{I}{k r}\right), Q_{n}\left(\frac{I}{k r}\right)$ are the Lommel polynomials $[4]$ of degree $n$ in the variable $(1 / \mathrm{kr})$. In the notation of Watson, we have

$$
\begin{aligned}
& P_{n}\left(\frac{1}{r}\right)=R_{n, 0}(r) \\
& Q_{n}\left(\frac{1}{r}\right)=R_{n-1,1}(r)
\end{aligned}
$$

Consider now the series

$$
E(w, \theta)=\sum_{0}^{\infty} \frac{u_{n}(b) \cos \left(n \theta+\gamma_{n}\right)}{H_{n}(k b)} P_{n}(w)
$$

$$
Q(w, \theta)=\sum_{0}^{\infty} \frac{u_{n}(b) \cos \left(n \theta+\gamma_{n}\right)}{H_{n}(k b)} Q_{n}(w)
$$

where $w$ is a complex varlable. Replace $w$ by ( $1 / k b$ exp $i \alpha)$ where $0 \leq \alpha \leq 2 \pi$, and $b$ is a fixed positive number greater than $a$. Then, for example, we can rewrite (13a) as follows:

$$
E(1 / k b \exp 1 \alpha \theta)=\sum_{n=0}^{\infty} \frac{u_{n}(b) \cos \left(n \theta+\gamma_{n}\right)\left(\frac{n}{n !}\right)\left(\frac{k b}{2}\right)^{n} e^{i n \alpha}}{\frac{n}{n \cdot\left(\frac{k b}{2} \exp i \alpha\right)^{n} H_{n}(k b)}}
$$


Now Hurwitz has shown $[4]$ that

$$
\lim _{m \rightarrow \infty} \frac{\left(\frac{z}{2}\right)^{v+m} R_{m, v+I}(z)}{\Gamma(v+m+I)}=J_{v}(z)
$$

Let $\mathrm{z}=\mathrm{kb} \exp 1 \alpha=1 / \mathrm{w}$. Hence, by (12) we have

$$
\lim _{\mathrm{I} \rightarrow \infty} \frac{n P_{n}\left(1 / k b e^{i \alpha}\right) \cdot\left(\frac{k b e^{1 \alpha}}{2}\right)^{n-1}}{n !}=J_{-I}\left(k b c^{1 \alpha}\right)
$$

On the other hand, for real $b$, we know $[5]$ that

(17)

$$
\lim _{n \rightarrow \infty} \frac{n\left(\frac{k b}{2}\right)^{n}}{n !} H_{n}(k b)=-\frac{1}{\pi}
$$

and we recall that

$$
\left|u_{n}(b) \cos \left(n \theta+\gamma_{n}\right) e^{-\ln \alpha}\right|<0\left(\frac{1}{n^{p}}\right)
$$

for arbitrary p. These considerations show that the series on the right side of (14) is uniformly and absolutely convergent. Now the series (13a) is a series of polynomials in $w$, which, as we have just seen, converges uniformly and absolutely for $|w|=I / k b$. Hence that series converges for $|w|<I / k b$ and defines an analytic function. Thus the right side of the first equation of (13) is convergent 
for $|\mathrm{w}|<\frac{\mathrm{l}}{\mathrm{kb}}$. The same is easily seen to be true of the second equation of (13). Therefore using (9) and (11) we deduce

Lemma I: If $u(r, \theta)$ is an outgoing wave function in two variabIes, regular outside a circle $r=a$, then

$$
\begin{aligned}
u=H_{0}(k r) \sum_{n=0}^{\infty} \frac{u_{n}(b) \cos \left(n \theta+\gamma_{n}\right)}{H_{n}(k b)} R_{n, 0}(k r) \\
+H_{I}(k r) \sum_{n=0}^{\infty} \frac{u_{n}(b) \cos \left(n \theta+\gamma_{n}\right)}{H_{n}(k b)} R_{n-I, I}(k r)
\end{aligned}
$$

where $R_{n, 0}$ and $R_{n-I, I}$ are polynomials of degree $n$ in the variable (I/kr), and where the series converge uniformly and absolutely for $r \geq b>a$. The series also converge uniformly and absolutely for a complex $r$, if $|r| \geq b>a$.

This Lemma easily implies Theorem II of the Introduction, since the uniform convergence of the series for $E$ and 0 , of ( $13 a$ ) and (1.3b) shows that $E$ and $O$ are analytic functions of $(I / r)$ in the circle $(I / r)<I / b$ in the complex $I / r$ plane. Theorem $I$ is a trivial corollary of Theorem II.

III. DETPRMTNATION OF THE COEFFICIENTS

We have thus far demonstrated the existence of a convergent expansion of the form given in equation (4). It is now appropriate to show how to determine the coefficients in this expansion. We consider two cases: In the first case $u$ is given on some circle $r=b>a$. 
In the second case the complex far field amplitude $f_{0}(\theta)$ is given:

The first case is trivial. In fact, the series (9) will supply the coefficient $u_{n}(b)$ and the phase angles $\gamma_{n}$. These can be inserted in (19) and the resulting series can be rearranged in descending powers of $r$, by the Weierstrass double-series theorem.

It is of greater interest to construct the series. (4) when we are given data at $r=\infty$. Suppose therefore that we are given the complex far field amplitude $f_{0}(\theta)$, where, by (2)

(20) $\quad \lim _{r \rightarrow \infty} \sqrt{\frac{\pi k r}{2}} u \exp \left(-i k r+\frac{i \pi}{4}\right)=f_{0}(\theta)$

Notice that $F_{0}(\theta)=E(0, \theta)$ and $G_{0}(\theta)=O(0, \theta)$. It is easily seen that, if the functions $F_{0}(\theta), G_{0}(\theta)$ of equation (14) are given, then $F_{n}$ and $G_{n}$ can be computed recursively. To see this fact, simply substitute (4) into the equation $\nabla^{2} u+k^{2} u=0$, and express all derivatives of $\mathrm{H}_{0}$ and $\mathrm{H}_{I}$ in terms of $\mathrm{H}_{0}$ and $\mathrm{H}_{I}$, by means of the recurrence formulae,

$$
\begin{aligned}
& \mathrm{H}_{0}^{\prime}=-\mathrm{H}_{I}, \quad \mathrm{H}_{0}^{\prime \prime}=+\frac{I}{r} \mathrm{H}_{I}-\mathrm{H}_{0} \\
& \frac{2 \mathrm{H}_{I}^{\prime}}{r}=\frac{-2 \mathrm{H}_{0}^{\prime \prime}}{r}, \mathrm{H}_{I}^{\prime \prime}=-\left(\frac{I}{r} \mathrm{H}_{I}-\mathrm{H}_{0}\right)^{\prime}
\end{aligned}
$$

Then collect the terms multiplying $\mathrm{H}_{0}$ and $\mathrm{H}_{I}$. The net coefficients of $\mathrm{H}_{\mathrm{O}}$ and $\mathrm{H}_{I}$ must vanish identically, and this gives expressions for $F_{n}, G_{n}$ in terms of $F_{0}$ and $G_{0}$. For example we find 
(22)

$$
F_{1}=-\frac{1}{2}\left(G_{0} "+G_{0}\right)
$$

$$
G_{1}=\frac{1}{2} F_{0}^{n}
$$

Therefore the problem is really to find $F_{0}$ and $G_{0}$, given $f_{0}(\theta)$. In order to find $F_{0}$ and $G_{0}, 1 . e \cdot \cdot$, to deduce the result given in Theorem III, we notice first that, as $r \rightarrow \infty$,

$(21 a)$

$$
\mathrm{H}_{\mathrm{n}}^{(1)} \sim(-1)^{\mathrm{n}} \tilde{\mathrm{H}}_{\mathrm{O}}(1)
$$

$(21 b)$

$$
\mathrm{H}_{\mathrm{n}}^{(2)} \sim(+\mathrm{i})^{\mathrm{n}} \tilde{\mathrm{H}}_{\mathrm{O}}^{(2)}
$$

where

$$
\text { (2Ic) } \quad \tilde{H}_{0}(1) \equiv \sqrt{\frac{2}{\pi k r}} e^{i\left(k r-\frac{\pi}{4}\right)} ; \tilde{H}_{0}^{(2)}=\sqrt{\frac{2}{\pi k r}} e^{-1\left(k r-\frac{\pi}{4}\right)}
$$

Also, we have

$$
H_{0}^{(m)}(k r) P_{n}+H_{I}^{(m)}(k r) Q_{n}=H_{n}^{(m)}(k r), \quad m=1,2 .
$$

These equations show that as $r \rightarrow \infty$

$$
P_{n}-i Q_{n} \rightarrow(-1)^{n} ; P_{n}+1 Q_{n} \rightarrow(+i)^{n}
$$

and, consequently, that 
(24)

$$
\left.\begin{array}{ll}
\mathrm{P}_{2 \mathrm{p}} \rightarrow(-1)^{\mathrm{p}}: \mathrm{P}_{2 \mathrm{p}+1} \rightarrow 0 \\
\mathrm{Q}_{2 \mathrm{p}} \rightarrow 0 & : \mathrm{Q}_{2 \mathrm{p}+1} \rightarrow(-1)^{\mathrm{p}}
\end{array}\right\} \quad \text { for } r \rightarrow \infty
$$

Therefore, by (19) and (21a) and (22), we have

(25)

$$
f_{0}(\theta)=\sum_{n=0}^{\infty} \frac{u_{n}(b)(-i)^{n}}{H_{n}^{(1)}(k b)} \cos \left(n \theta+\gamma_{n}\right) .
$$

But, since $F_{0}(\theta)=E(0, \theta), G_{0}(\theta)=O(0, \theta)$, we find, by letting $r \rightarrow \infty$ in (4a) and by using (21a) and (4), that

$$
f_{0}(\theta)=F_{0}(\theta)-i G_{0}(\theta)=E(0, \theta)-i 0(0, \theta)
$$

Furthermore, if we use (19) and (12), and exploit the simplification introduced by (24), we find that $F_{0}(\theta)$ contains only even-numbered Fourier coefficients, and $G_{0}(\theta)$ contains only odd ones. In fact

$$
\begin{aligned}
& F_{0}(\theta)=\sum \frac{u_{2 p}(b)(-1)^{p}}{H_{2 p}(k b)} \cos \left(2 p \theta+\gamma_{2 p}\right) \\
& G_{0}(\theta)=\sum \frac{u_{2 p+1}^{(b)}(-1)^{p}}{H_{2 p+1}(k b)} \cos \left[(2 p+1) \theta+\gamma_{2 p+1}\right] .
\end{aligned}
$$

If we compare (25) with (27), we find, in view of (26), the result expressed in Theorem III of the introduction. Thus we have expressed $F_{0}, G_{0}$ in terms of $f$, as we desired. 


\section{BIBIIOGRAPHY}

[1] Wilcox, C. H.

[2] Sommerfeld, A.

[3] Zitron, N. and Karp, S. N.

[4] Watson, G. IN.

[5] Müller, C.
- An expansion theorem in electromagnetic fields, 9, 45-134 (1956). See also R. B. Barrar and A. F. Kay - A serles development of the wave equation 1 n powers of $1 / r$. Tech. Res. Group, N.Y.C. - a report referred to in $[I]$.

- Partial Differential Equations in Physics, N.Y., Academic Press, 1949, p. 192.

- Higher order approximations in multiple scattering - I. Two-dimensional scalar case. N.Y.U., Inst. Math. Sc1., Div. EM Res., Report No. EM-162, Mar., 1959.

- Theory of Bessel Functions, Camb. U. Press, 1958, pp. 294-303, esp. p. 302.

- Grundprobleme der mathematischen Theorie elektromagnetischer schwingungen, Berlin, Springer-Verlag, 1957, p. 79. 
Contrect No. AF $19(604) 5238$

(ONE copy unless otherwise noted)

Commander

A1r Research and Development Command

Andrews A1r Force Base

Washington 25, D. C.

Atin: Major E. Wright, ROTCC

Director of Resident Training

33Roth Technical Training Oroup

Kaesler Air Force Base, M1sstss1ppi

Attn: OA-3011 Course

Director

Alr University Library

Maxwell Air Force Bage, Alabama

Commander

Air Force Misile Test Center

Patrick Air Forca Base, Florida

Attn: MTE - for classified documents

Attn: MU-411, Technical Library - for unclesg1fied documents

Tactical Air Group

Directorate of Resesrch and Devel spment DCS/D

Headquarters, IJSA

Washington, D. C.

Attn: Major R. L. Stall

Director, Communfeations and Electronics Hq. U. S. A1r Force

Washington 25, D. C.

Attni AFOAC $S$ /

Commander

Wright Alr Development Center

Wright-Patterson Air Force Bage, Oh10

Attn: WCLRS-6, Mr. Fortune

Wright A1r Development Center

Wright-Patterson Afr Force Basa, Oh10

Flight Research Laboratory

Rasearch D1vision

Attn: WCRRA

\section{Commander}

Wright A1r Develooment Center

Wright-Pattergon A1r Force Base, Ohlo
Attn: N. Drsganjac, WCLNQ-4

\section{Commender}

Wright Air Development Center

Wright-Patteraon Air Force Base, Ohio

Attni Mr. Paul Springer, WCLRE-5

Commanier

A1r Technical Intelligence Center

Wright-Fattaraon Air Force Base, Ohio

Attn: $A$ TCTN-1,Bia

Commander

Rome Air Develapment Cantar

Griffles A1r Force Base, New York

Attn: RCSSTL-1

\section{Commander}

Rome Afr Development Center

Grifflss Air Force Base, New York

Attra Mr. Donsid Dakan, ReUE

\section{Comander}

Rome A1s Development Center (ARDC)

Griffiss Air Forca Bsse, New York

Attn: Dr. John S. Burgess, RCE

\section{Comander}

A1r Force Misglle Development Center

Holloman Alr Force Base, Now Mexico

Attn: HDIn, Technical Library

Diractor

V. S. Amp Ordinance

Ballistic Ressarch Laboratories

Aberdeen Proving Ground, Marvland

Attn: Ball1stic Meagurements Laborator

Ballistic Regearch Laboratorles Aberdean Proving Ground, Maryland Attn: Technical Informstion Eranch
Director

Evans Signal Eabaratory

Belmar, New Jargey

At.tn: Mr. O. C. Woodyard

U. S. Amny Signal Engineering Labs.

Evans Stgnal Laboratory

BeImar, New Jersey

Attn: Trchnical Document Conter

Masaachusetts Institute of Technology Signal Corps Liaison Officer

Cambridge 39, Mass.

Attn: A. D. Bedrosian, Roon 26-131

Commanding General, SIGFM/EL-PC

U. S. Army Signal Engineerlng Labs.

Fort Monmouth, New Jersey

Attn: Dr. Horst H. Kedesdy Deputy Chief, Chem-Physics Branch

Companier

Amry Rocket and Culded Mesilo Agency

Redstone Araenal, Alabama

Attn: Technical Library, OROXR-?TL

Commanding General

U. S. Army Signal En ineering Labs.

Fort Monnouth, New Jersey

Attn: SIGFM/EL-AT

Department of the Artay

Offlce of the Chief Signal officer

Washington 25, D. C.

Attn: SIGPD-?

office of Chief Signal officer

Enginaering and Technical Division

Washington 25, D. C.

Attn: SIGNET-5

Gulded Missile Fuze Library

D1amond Ordnance Fuze Laboratories

Washineton 25, D. C.

Attn: R. D. Hatcher, Chief Microwavo Devolopment Section

(10) Armed Services Technical Information Agency

Arlington Hall Station

Arlington 12, Virginia

(2) Library

Boulder Laboratorlea

Netional Bureau of Standsrds

Boulder, Colorado

National Burasu of Standardo

Department of Commerca

Weshington 25, D. C.

Att.n: Mr. A. G. MeNish

National Bureau of Standards

Department of Commerce

Washington 25, D. C.

Attn: Gustave Shapiro, Chief

Engineering Electronics Section

Electricity and Electronics Div.

(2) Office of Technlcal Services

Department of Cormerce

washington $25, D$. C.

Attn: Technical Reports Section (Unclassiftad only)

Director

National Security Agency

Washington 25, D. C.

Attn: $\mathrm{R} / \mathrm{D}(331)$

(2) Hn. Alr Force Cambridge Research Center Laurance G. Hanscom Field

Bedford, Mass.

Attn: CROTLR-2 - P. Candon

(5) HQ. A1r Force Cambridge Research Center Laurence G. Hangcom Field

Bedrord, Mass.

Attn: CROTLS - J. Armstrong
(5) Hq. Als Forca Cambridga Research Center Laurence G. Hanscam Field Bedford, Mass.

Attn: CRRO

Diractor, Avionics DAvision (AV)

Bureau of Aeronautics

Department of the Navy

Washington 25, D. C.

Chief, Bureau of Ships

Department of the $\mathrm{NaVy}$

Washineton 25, D. C.

Attn: Mr. E. Johnston, Code B33E

Commandar

T. S. Naval Afr Missile Test Center

Point Mugu, California

Attin: Code 366

U. S. Naval Ordnance Laboratory

White Oak

Silver Spring 19, Marlland

Attn: The Library

Commander

U. S. Naval Ordnance Test Station

China Lake, California

Attn: Code 753

Librarian

U. S. Naval Poatgraduate School

Montarey, California

Alr Forsa Development Field Representative Naval Research Laborstory

Washington 25, D. C.

Attn: Code 1072

Director

U. S. Naval Research Laboratory

Wrshington 25, D. C.

Attn: Code 2027

Dr. J. 1. Bohnert, Code 5210

U. S. Naval Resesrch Laboratory

Washington 25, D. C. (Unclassified only)

Classified to he sent to

Director

U. S. Naval Research Laborat,ory

Attn: Code 5200

Washington $25, \mathrm{D} . \mathrm{C}$.

Comanding officer and Director

U. S. Navy linderwbter Sound Lahoretory

Fort Trumbu11, New Londan, Connecticut

Chief of Naval Research

Departinent of the Mavy

hashington 25, D. C.

Attn: Code 42 ?

Commanding of ficer and Director

IT. S. Nary Electronica Laboratory (Library)

Sen Diego 52, California

Chief, Bureav of Ordnance

Departiment of the Navy

Washington 25, D. C.

Attn: Code Ad3

Chief, Bureay ar Ordnance

Department of the Navg

Surface Gulded Misslie Branch

Washington 25, D. C.

Attn: Code ReSl-e

Chief, Buraay of Ordnance

Department of the Navy

Washington 25, D. C.

Attn: Fire Control Branch (ReSu)

Department of the Navy

Bureau of Aeronautics

Technical Data Division, Code 4106

Washington $25, D, C$.

Chief, Buresu of Ships

Department of the $\mathrm{Navy}$

Waehington 25, D. C.

Attn: Code 8178 
Commanding off 1 cer

T. S. NavaI Air Development Center

Johnsvilie, Pennsylvanda

ettn: NADC Lihrary

Commander

U. S. Navel Air Tegt Center

Patuxent R1ver, Maryland

Attn: ET=315. Antenna Branch

Director

Naval Crdnance Laboratory

Corona, Californis

Commanding officer

U. S. Naval Ordnance Lahoratory

Corona, California

Attn: Mr. W. Horenstein, D1vision 72

A frbome Instrumenta Lahoratory, Inc.

lto old Country Road

Mineola, New York

Attn: Dr. E. C. Fubini, Director Research and Engineering Division

A1 rcom, Inc.

354 Main Street

winthrop, Mass.

Amer1can Machine and Foundry Company

Electronica Divigion

loR5 Commonwealth Avenue

Boston 15, Mass.

Attn: Mrg. Rita Moravcalk, Librarlan

Andrew Alford, Consulting Engineers 299 Atlant1c Avenue

Boston 10, Maso.

Avion Division

ACF Industries, Inc.

800 No. Pitt Street

Alexandria, Virginta

Attn: Library

Battelle Menorlal Ingtitute

$505 \mathrm{King}$ A verue

Attn: Wame E. Rufe, Profect Leader

Electrical Engineering Divigion

Columbua 1, Ohio

\section{Bell Alrcraft Corporation}

Post office Box One

Buffalo 5, New York

Attn: Eunice P. Hazelton, Librarian

Be1l Telephone Laboratorifs, Inc.

Whippeny Laboratory

Whippany, New Jersey

Attn: Technical Information Lihrary

Pacific D1vision

Bendix Avlation Corporation

11 too Sherman Way

North Hollywood, California

Engineering Library

Attn: Peggie Robingon, Librartan

Bendix Radio Division

Pendix Aviation Corp.

E. Joppe Road

Towson 4 , Maryland

Attn: Dr. D. M. Alligon, Jr.

Director Engineering and Resaarch

Boelng Alrplane Company

Pilotless Aircraft Division

P.n. Box 370 ?

Seattle 24, Washington

Attn: R.P. Barber, Library Supervisor

Boeing Alrplane Company

Wichlta Division Engl neering Lforary

Wich1ta 1, Ransas

Attn: Kenneth C. Knight, Librarian

Boeing Alrplane Comrany

Seattle Division

Seattle 14, Waahington

Attn: E.T. Allen, Llhrary Supervigor

BJorksten Rogearch Labs, Inc.

P. O. Box 265

Madison, Wiscongin

Attn: Mrs. Fern B. Korggard
Conva1r, A Division of General Dynamics Corp.

Fort Worth, Texas

Attn: K.G. Brown, DIvigion Research Librarian

Convair, A Division of General Dynamics Corp.

San Diego 12, Californts

Attn: Mrs. Dora B. Burke, Engineering Librarian

Comell Aeronautical Iaborator, Inc.

hil 55 Genegee Street

Ruffalo 21, New York

Attn: Librarian

Dalmo Victor Company

A Division of Textron, Inc.

1515 Industrial Way

Relmont, Californta

Attn: Mary Ellen Addems, Technical Librarian

Dorne and Margolin, Inc.

29 New York Avenue

Westbury, Long Island, N. Y.

Douglas A Ircraft Compeny, Inc.

P. . BOx 200

Long Beach 1, Californis

Attn: Engineering Library (C-250)

Douglas Alrcraft Co., Inc.

R2? Lapham Street

EI Segundo, Californis

Attn: Engineering Library

Douglas Afrcraft Company, Inc.

3000 Ocean Park Boulevard

Santa Monlca, California

Attn: P.T. Cline

Eq. Sec. Reference files,

Eq. Eng. A250

Douglas Alreraft Company, Inc.

2noO North Memorial Drive

Tulsa, Ok lahoma

Attn: Engineering Lthrary, D-250

Electronteg Communteation, Inc.

1930 York Road

Timontum, Maryland

Emergon and Cuming, Inc.

969 Washington Street

Canton, Mass.

Attn: Mr. W. Cuming

Emergon Electric $\mathrm{Kfg}$. Co.

8100 West Florlssant A venue

St. Louis 21, M1saourt

Attn: Mr. E.R. Brealin, Librarian

Sylvanta Elec. Prod. Inc.

Electronic Defenge Laboratory

P.O. Box 205 - (Unc1)

Mountein View, Califortia

Attn: Library

Fairchild Aircraft Diviaion

Falrchild Eng. and Alrplane Corp.

Hagerstown, Marvland

Attn: Lihrary

Farngworth Electronics Company

3700 East Pont1ac Street

Fort Wayne 1, Indiane

Attn: Technical Library

Federal Telecommunication Labg

500 Washington A venue

Nutiey in, New Jersey

Attn: Technical Library

The Gabriel Electrontcs

Divigion of the Gabriel Company

135 Crescent Road

Needham Heights 94, Masa.

Attnt Mr. Steven Galagan
General Electric Advanced Elactrontcs Center

Cornell Und versity

Ithaca, New York

Attin: J. B. Travis

General Electric Comparv

Electrontes Park

Syracuge, New York

Attn: Docunertg thram, B. Fletcher Bullding 3-143A

General Precigion Laboratory, Inc.

63 Bedford Rond

Pleasant ville, New York

Attn: Mrs. Mary G. Herbst, Ithrartan

Goodvear Alrcraft Corp.

1210 Masallion Road

Akron 15, Ohto

Attn: Library $\mathrm{D} / 120$ Plant $A$

Granger Associates

Electronic Sygtems

966 Comercial Straet

Palo Alto, California

Attnt John $V$. N. Granger, Presidont

Grumman Aircraft Eng1nearing Corporation Bethpage, Long Island, N. Y.

Attn: Mrs. A. M. Grav, Librarian Engineerlng Library, Plant No. 5

The Halifcrafters Company

Whol Weat 5 th Avenue

Chicago 24, Illinols

Attn: LaVerne Lacioia, Librarian

Hoffman Laboratoriea, Inc.

3761 South Hill Street

Los Angeles?, Californta

Attn: Englneering Library

Hughes Alrcraft Company

Antenna Department

Microwave Laboratory

Bullding 12, Room 26l?

Culver City, Calif ornta

Attn: M. D. Adcock

Hughes A 1 rcraft Company

Florence and Teale Streeta

Culver City, California

Attn: Dr. L.C. Van Atta, Assoctate Director Research Labs.

Hycon Eastern, Inc.

75. Cambridge Parkway

Cambridge, Mass.

Attn: Mrs. Lois Seulowtz Techntcal Librarian

International Business Machines Corp.

Military Products D1 vision

5 क Madison Avenue

New York 33, New York

Attn: Mr. C.F. MCElwain, reneral Manager

International Busineas Machines Corp.

Military Products Division

Owego, Naw York

Attn: Mr. D. I. Marr, Lihrarian Department $459^{\circ}$

International Registance Company

LOl N. Broad Straet .

Fh1ladelphia $8, \mathrm{~Pa}$.

Attn: Research Lihrary

Jansky and Batley, Inc.

1339 Wigcongin A venue, N. W

Washington 7, D. C.

Attn: $\mathrm{V}_{\mathrm{r}}$. Delmer C. Ports

Dr. Henry Jasik, Consulting Engineer 298 Shames Drive

Brush Hollow Indugtrial Park

Westbury, New York

Electromagnetic Research Cornoration 711 14th Street, N. W.

Washington $5, \mathrm{D} . \mathrm{C}$. 
Lockheed Afrcraft Corporation $2555 \mathrm{~N}$. Hollywood Way California Division Enginearing Library Department 72-75, Plant A-1, Bldg, 63-1 Rurbank, California Attn: N. C. Harnols

The Martin Company

P. O. Box 179

Denver 1 , Colorado

Attn: Mr. Jack McCormick

The Glenn L. Martin Company Baltimore 3, Maryland

Attn: Engineering Library

Antenna Design Group

Marvland Electronic Manufacturing Corp. 5009 Calvert Poad

College Park, Maryland

Attn: Mr. H. Warren Cooper

Mathenatical Reviewa

190 Hope Street

Providence 6, Rhode Island

The W. L. Maxson Corporation

460 West 3 hth Street

New York, N. Y.

Attn: Misa Dorothy Clark

McDonnell Aircraft Corporation

Lambert Saint-Louls Municipal Airport

Box 516. St. Louis 3, Missourt

Attn: R. D. Detrich, Engingering Library

McMillan Laborato:y, Inc.

Erowmille Avenue

Ipswich, Masgachusett

Attn: Security Off1cer. Document Roon

Melpar, Ine.

3000 Arlington Boulevard

Falls Church, Virginis

Attn: Engineering Technical Library

Microwave Development Laboratory

90 Broad Strget

Babson Park 57, Masaachugetts

Attn: N. Tucker, General Manager

Microwave Radiation Company Inc.

19223 South Hamilton Street

Gardena, Californta

Attn: Mr. Morr19 J. Ehrlich, President

Chance Vought Aircraft, Ino.

9314 West Jefferson Street

Dallas, Texas

Attn: Mr. H. S. White, Librarian

Northrop A1rcraft, Inc.

Hawthorne, California

Attn: Mr. E. A. Freltag, Library Dept 3145 1001 E. Broadway

(2) The Ramo-Wooldridge Corporation

P.n. Sox 145153 Afrnort Station

Los Angeles 15, California

Attn: Margaret C. Whitnah, Chief Librarian

Hoover Microwave Co.

9592 Baltimore Avenue

College Park, Marvland

Director, USAF Profect RAND

Via: A1r Force Lialson Of pice

The Rand Corporation.

1700 Main Street

Santa Monica, California

Rantec Corporation

Calabasas, California

Attn: Grace Keener, Office Nanager

Raytheon Manufacturing Company

Misgile Systems Divigion

Bedford, Mass.

Attn: Mr. Irving Goldstein

Remington Rand Univ. - Division of Sperry

1900 West Allegheny Averue

Philadelphia 29, Pennsyl varia

Attn: Mr. John F. MeCarthy $R$ and $D$ Salea and Contracts

North American Avlation, Inc.

12214 Lakewood Boulevard

Dowey, California

fttn: Engineering Library 495-115

North American Aviation, Inc.

Los Angeles International Airport

Los Angeleg 15, Californta

Attn: Entneering Technical File

Page Communications Engineers, Inc.

710 Fourteenth Street, Nor thwest

Whahington 5, D, C.

Attn: Librarian

Philco Corporation Resaarch Division

Branch Library

4700 Wissachickon A venue

Philadelphia 4h, $\mathrm{Pa}$.

Atin: Mrs. Dorothy S. Collins
Raytheon Manufacturing Company

Wayland Laboratory, State Road

Wayland, Mass.

fitn: Mr. Robert Borts

Baytheon Manufactur1ng Comrany

Wayland Laboratory

Wayland, Mass.

At.tn: Miga Alice G. Anderson, Librarian

Republ1c Avition Corporation Farmingdale, Long Island, N. Y.

Attr: Eng1neering Lihrary

Thru: Alr Force Plant Representative Farmingdale, Long Island, N.Y.

Rheem Manu'acturfng Conpany

9236 Erat Hall Road

Downey, California

Attn: J. C. Joerger

Trans-iech, Inc.

P. 0 . 50x 346

Frederlck, Maryland Republic Aviation Corp.
Pyan Aeronautical Comnany

indhergh Field

San Diego 12, Californa

Attn: Library - unclasajfied

Sage Laboratcríes

159 Linden Streat

Wellesley 81 , Mass.

Gandorg Associates

95 Canal Street

Nashua, New Hampshirc

Attn: N. R. 'Nild, Lihrary

Sandia Corporition, Sandia Base

P.0. Sox 5900, Albu zuer jue, New Mexico

Attn: Classified Document Divialon

Sperry Gyroscope Company

Creat Neck, Long Island, New York

Atn: Florence W. Turnbull, Engr. Librarian

Stanford kesearch Institute

Menio Park, Callfornla

Attn: Library, Englneerine Division

Svivania Electric Products, Inc.

ino First Avenus

NaItham 5h, Mass.

Attn: Charles A. Thornhil1, Report Librarian Walthan Lahoratorles Iifrary

Systems Lahoratorieg Corporation

Wha52 yentura Boulevart

Shoman Naka Calpromis

Attn: Donald L. Margerum

T:3, Ine.

17 Union Jquare Wigst

New York 3, N. Y.

Attn: M. L. Henderson, Librarian

A. Thomas, Inc.

161 Devonshire Street

Boston 10, Mass.

A.tn: A. S. Thomas, President

Bell Telephone Laboratories

Murray Hill

New Jersey

Chu Assoclates

P. O. Box 387

Whitcomb Avenue

Littletor, Mass.

Merowave Associates, Inc.

Burlington, Masa.

Paytheon Nanufacturing Company

Misalle Mivision

Hartwell Road

Redford, Mass.

Radio Corporation of America

A viation Systems Iaboratory

225 Crescent Street

Naltharm, Maas.

Lockhed Aircraft Corporation

Missile Systems Dirision Pesearch Library

Box 50h, Sunnyvale, California

Attn: Misa Eva Lou Robertson, Chief Librarian

The Rand Corporation

1700 Main Straet

Sant a Monica, California

Attil: Dr. W. C. Hoffman

Cumanier

$A F$ Offica of Scientific Research

Afr Research and Development Command

listh Street and Constitution A venue

Washington, D. C.

Attn: Mr. Nting, SPY

Wegtinghouse Electric Corp.

Elactronics Diviaion

Friendahip Jnt'1 A1rport Box $7 / 56$

Aaltimore 3, Marvl and

Attn: Engineering Library 
Wheeler Laboratories, Inc.

122 Cutter Mill Road

Creat Neck, New York

Attn: Mr. Harild A. Wheeler

Zenith Plastics Co.

Box 91

Gardene, Calffornia

Attn: Mr. S. S. Oleesky

Library Geophysicel Institute

of the Bniversity of Alasks

college

Alagk

Univergity of Cal1fornis

Berkeley L, Callfornia

Attn: Dr. Samuel Silver,

Prof. Engineering Science

Division of Elec. Enz. Electronics Research Lab.

"Niversity of California

Electronics Regearch Leb.

332 Cory $\mathrm{Hell}$

Rerkeley L, Californie

Attn: J. R. Whinnery

Californis Institute of Technology

Jet Propulsion Laboratory

4800 Dek Grove Drive

Pasedena, California

Attn: Mr. I. E. Newlan

California Institute of Technology

1201 E. Coliforni a Streot

Pagadena, Celifornda

Attn: Dr. C. Papas

Garnegie Institute of Technology, Schenley Park

Pitt sburgh 13, Pennsyl vania

Attn: Prof. A. E. Helns

Cornell lndversits

School of Electrical Enzineering

Ithace, New York

Attn: Prof. G. C. Dalman

I'niversity of Florida

Department of Electricsl Engineering

Gainesulle, Florida

Attn: Prof. M. H. Latour, Library

Lihrary

Georgie Institute of Technology

Engineering Experiment Station

At lanta, Georela

Attn: Mrs. J.4. Crosland, Librarien

Harvard Infuergity

Technical Reports Collection

Gordon Mckay Library, 303A Plerce Hall

Oxford Street, Cambridge 3R, Mass.

Attn: Mrs. E.L. Hurschmidt, Librarian

Harvard College Observatory

$\left({ }^{\circ}\right)$ Garden Street

Cambridge 37. Mess.

Attn: Dr. Fred L. Whipple

Iniversity of Illinois

Documenta Division Library

Urbane, Ilinois

University of Illinois

College of Engine ering

Urbane, Illinols

Attn: Dr. P. E. Moyes, Department of Electricel Engineering

The Johns Hopkins University

Homewood Cempus

Department of Physics

Baltimore 18, Marylant

Attn: Dr. Donald E. Kerr

Sandie Corporation

Atton: Organization $1 / 23$

Sandio Bese

Alburuerrue, New Mexico
Applied Fhyalcs Laboratory

The Johns Hopkins University

8621 Georgia A vanue

Silver Spring, Maryland

Attn: Mr. George L. Selelstad

Massachusetts Institute of Technology

Research Laboratory of Electronfcs

Room 2OB-22]

Cambridge 39, Massachusetts

Atts: John H. Hewitt

Messechusetts Institute of Technology

Lincoln Laboratory

P. 0. Box 73

Lexington 73, Mass.

Attn: Document Room A-229

University of Michtgan

Electronic Defense Group

Engineering Research Institute

Ann Arbor, Michigan

Attn: J. A, Boyd, Supervisor

University of Michigan

Engineering Research Institute

Radiation Laboratory

Attn: Prof. K. M. Stegel

912 N. Mein St.

Ann Arbor, Michigan

Univergity of Mlchigan

Englneering Research Ingtitute

Willow Run Laboratories

Willow Run Airport

Ypsilant1, Michigan

Attn: Lubrartan

Iniversity of Minnesota

Minneapolis 14 , Minnesota

Attn: Mr. Robert H. Stum, Librery

Northwestern University

Microwave Laboratortes

Evanston. Illinols

Att n: R. E. Beam

Ohio Stote University Research Found.

Ohio State Untversity

Columbus 10 , Ohio

Attr: Dr. T.E. Tice Dept. of Elec. Engineering

The University of Oklahoma

Research Ingtitute

Nornan, Oklehoma

Attni Prof. C. L. Farrer, Chairman Electrical Engineering

Polytechnic Institute of Brooklym

Microwave Research Institute

55 Johnson Street.

Brooklym, New York

Attn: Dr. Arthur A. Oliner

Polytechnic Institute of Brooklym

Microwave Research Inatituto

55 Johnson Street

Bronklym, New York

Attn: Mr. A, E. Laemmel

Syracuse University Research Ingtitute

Collendale Campus

Syracuse 10, New York

Attn: Dr. C. S. Grove, Jr.

Director of Engineering Research

The Vniversity of Texas

Elec. Engineering Research Laboratory

P. 2. Box 8026, University Station

Austin 12, Texas

Attn: Mr. John R. Gerhardt

Assistant Director

The lniversity of Texas

Defense Research Laboratory

Austin, Texas

Attn: Claude W. Horton, Physics Library

University of Toronto

Department of Electrical Engineering

Toronto, Canada

Attni Prof. G. Sinclair
Lowell Technological Institute

Fesearch Foundation

F. O. Box 709, Lowell, Mass.

Attr: Dr. Charles R. Mingins

Univeraity of Washineton

Department of Electrical Ersineering

Seattle 5, hashingt on

Attin: G. Held, Associate Professor

Stanford Uni versity

Stanford, California

Attn: Dr. Chodorow

Microwave Laboratory

Phyalcel Science Laboratory

New Mextco Colle 5 of Agriculture

and Mechanic Arts

State College, New Mextco

Attn: Mr. H. W. Has

Brown University

Department of Electrical Engineering

Providence, Rhode Island

Attr: Dr. C. M. Angulo

Gase Institute of Technology

Clevalend, Ohio

Attn: Prof. S. Seeley

Columbia Und versity

Department of Electrical Engineering

Morningalde Heights

New York, N. Y.

Attn: Dr. Schlesinger

McGill Univergity

Nontreal, Canada

Attn: Prof. G. A. Woonton

Director, The Eaton Electronics Research Lab.

Purdue Oniversity

Department of Electrical Engineering

Lafayette, Indiana

Attn: Dr. Schult

The Pennsylvania State University

Department of Electrical Engineering

University Park, Pennsvivania

University of Pennsvlvania

Institute of Conperative Regearch

3 hoo Walnut Strent

Philadelphia, Pennsyl vanie

Attn: Deot. of Electrical Engineering

Intversity of Tennessee

Ferris $\mathrm{Hall}$

W. Cumberland Avenue

Kroxville 16, Tennessee

Und versity of Wisconsin

Department of Electrical Engl neering

Matison, Wisconsin

Attn: Dr. Schefbe

University of Seattle

Department of Electrical Engineering

Seattle, Washington

Attr: Dr. D. K. Reynolds

Wayme University

Detroit, Michigan

Attn: Prof. A. F. Stevenson

Electronfes Research Lsboratory

IIlinois Institute of Technology

3300 So. Federal Street

Chicago 16, Illinois

Attn: Dr. Lester C. Peach

Research Engineer

Advisory Group on Electronic Parts

Roor 103

Moore School Building

200 South 33 rd Street

Philadelphia 4, Pennsylvanta 
Ionosphere Research Laboratory Pennsylvania Stata College State College, Pennsylvania ATT, Professor A. H. Wavnlck, Director

Institute of Mathematical Sciences 25 Haverly Place

Now York 3, New York

ATTN L Librarian

Electronice Division

Rand Corporation

1700 Maln Street

Santa Monica, California

ATTN: Dr. Robert Kalaba

National Bureau of Standarts

Waghington, D. F.

ATTN: Dr. N. K. Saunders

Applied Mathematies and Statisties Lab.

Stanfor! Uni rersit

Stanford, alifomla

ATTN: Dr. Albert H. Bowler

Department of Physicg and Astronomy

Michizan State College

East Lansing, Mich1pan

ATTM: Dr. A. Leitner

University of Tennessea

Knoxvlle, Tennessee

ATTN: Dr. Frel A. Flckan

Lehanon Valley College

Annutlie, Penneylvania

ATTN: Professor B.H. B1ssinger

Gencral Atomio

P. ว. B०X 608

San Diego 12, Ca]ffomia

attn: fr. Enward Gerjuoy

Dapartment of Physics

Amhergt Collage

Amherst, Mass.

ATT N Dr. Arnold Arons

Galffornia Institute of Technology

1201 E. Califomia Street

Pasadena, Californa

ATTN: Dr. A. Erdely

Mathematjcg Department

Stanford Unt versity

Stanford, Califnmia

ITTN: Dr. Harold Levina

University of Minnesota

Minnpapolis $11_{1}$, Minnesota

ATTN, Professor Paul C. Rosenbloom

Department of Mathematics

Stanford Ontversity

Stanford, Cal1fornia

ATTN: Professor Bernard Epstein

Applied Physics Laboratory

The Johns Hopk1ns Unt versity

8621 Gaorgis Avemue

Silver Spring, Maryland

ATTN: Dr. B. S. Gourary

(2) Exchange and Gift Divigion

The Library of Congrass

Washingtoon $25, \mathrm{D}, \mathrm{C}$.

Elactrical Eng1 neerlnz Department Maseachusetts Institutc of Technologt Cambridge 39, Mas9.

ATTN: Dr. I. J. Chu

Nuclear Davelopment Associates, Inc. 5 New Streat

White Pla1ns, New York

ATTN: LHbrary

Californis Institute of Technology

Electrical Enginearing

Pasadera, California

ATTN: Dr. Zohrab A. Kapriellan
Dr. Rodman Doll

31 W. Sross Street

Ypsilant1, Mich1zan

Calfomia Inat. of Technology

Pasalena, Callfornia

ATTN: Mr. Calvin WiIcox

(3) Mr. Robert Brockhurst

Woods Hola Oceanographic Institute

Woods Hola, Mass.

National Bureau of Standaris

Boulder, Colorado

ATTN: Dr. R. Gallet

Dr. Solomon L. Schwabal

3699 Louis Road

Palo Alto, dalifornia

University of Minnasota

The University of Library

Minneapolis I4, Minnesat

ATTN: Exchange Divigion

Department of Mathematics

Ilnivarsity of $\mathrm{Callf}$ omia

Barkelev, Calfomia

ATTN: Professor Bemart Friedman

Lincoln Laboratory

Maseachusetts Institute of Technology

P. O. Box 73

Laxington 73, Massachusetts

ATTN: Dr. Shou Chin Wang, Roam C-351

Melpar, Inc.,

3000 Aringtón Boulevard

Falls Church, VArginia

ATTN: Mr. Y.S. Kalleher, Section Heas

Ho. Alr Force Cambridga Resanrch Cantar Laurence G. Hanscom Field

Badford, Mass.

ATTV: Mr. Francis J. Zucker, CRRD

Hq. Alr Force Cambridge Researoh Center

Laurance $\mathrm{C}$. Hanscom Figld

Bedford, Maаs.

ATTN: Dr. PhIllp Newman, CRRK

Mr. N. C. Gergon

Trapelo Road

South IIncoln, Mass.

Dr. Richard B. Barrar

Syatems Development Corp.

$2 \zeta_{4} 00$ Colorado Avenus

Santa Mondea, California

Columbla Untvarsity Hudgon Laboratorlas P. O. Bax 233

145 Fallaade Street, Dobbs Ferry, N. T.

ATTN: Dr. N. W. Johnson

Institute of Fluid Dynamics

and Applied Methematics

Univarsity of Maryland

College Park, Maryland

ATTN: Dr. Elllatt Montroll

Department of Electrical Enginearing

Washington Univarsity

Saint Louls 5 , Mo.

ATTN: Prafessor J. Van Bladel

Department of the Navy

office of Naval Rasearch Branch office

$1030 \mathrm{E}$. Green Street

Pasadena 1, Cal1fornia

Brandeis University

Waltham, Mass.

ATTN: Library

General Electric Company

Mictowava Lahoratory

Elactronica Division

Stanford Induatrial Park

Palo Alto, Calipomia

ATTN: Lihrary
Simyth Research Associates

3555 Aero Court

San Diego 3, California

ATT: Dr. John B. Smyth

Electrical Engineering

California Institute of Technology

Pasadena, Californda

${ }^{1}$ TTV: Dr Georges G. Weill

Naval Regarah Laboratory

Washington 25 , D. C.

ATTN: Henry J. Pasgerini, Code 5278A

Dr. Feorge Kear

5 Culver Court

ortinda, California

Brooklyn Polytechnic

85 Livingstion Straet.

Brooklym, New York

ATTN: Dr. Vathan Marcuvitz

Dapartment of Elactrisal Enginaer1ng Brcoklyn Polytechnic

85 Livingaton Street

Erooklyn, New York

ATTN: Dr. Jerry Shmoys

Departmant of Mathemattea

Univargity of New Mexico

A Ihuzuerque, New Maxico

ATPN: DT. 1. Kolodner

Mathematica Department

Polvtechnic Inatitute of Brooklyn

Johnson and Jay Street.

Erooklyn, New York

ATTN \& Dr. Herry Hochstadt

Ballist1es Research Laboratory

Abardean Proving Grounds

Aberdeen, Marvland

ATTN: Dr. Pullan Reats

Dr. Laster Kraus

4935 Whit ehaven Way

San Diego, California

University of Minnesota

Institute of Technology

Minneapolia, Mi nnasota

Attn: Daan Athelston Spilhaus

Ohio State University

Columbus, Nhio

Attn: Prof. C. T. Tai

Department of Electrical Eng.

Naval Resaarch Laboratorieg

Washingt on 25, D. C.

Attn: W. S. Ament, Code 5271

Naval Rasearch Laboratory

Washington 25. D. C.

Attn: Dr. Lesl1B $\mathrm{G}$. McCracken, Jr. Code $3933 \mathrm{~A}$

Office of Naval Research

Dedartment of the Navy

Attn: Geophysics Branch, Coda 416

washington 25, D. C.

Offlce of Chief Signal Officar

Signal Plans and Pperationg Division

Attn: SIGOL-2, Room 20

Com. Liafson Br., Radio Prop. Sect.

The Pentagon, Washington 25, D. C.

Dafence Rasearch Member

Caradian Jolnt Starf

2001 Connecticut Straet

Washington, D. C.

Central Radio Prop. Lab.

National Bureau of Standard

Attn: Tochnical Reporte Library

Boulder, Colorado

U. S. Weathar Bureau

U. S. Department of Commerce

Waghincton 25, D. C .

Attn: Dr. Harry Wexler 
Federal Communtcations Comiaston Wash1niton 25, D. C.

Attn: Mrs. Barbara C. Grimes, Librarian

Unper Atmosphere Rasearch Section Central Radio Propagation Laboratory Vattonal Bureau of Standards

Boulder, Colorado

Argonne Vational Lahoratory

P. ก. Rox 290

Lemont, Illinota

Attn: Dr. Hoylande D. Young

Bell Telephone Laba.

Murrap Hill, New Jersey

Attn: Dr. S. O. Ritce, $39-203$

Carnegie Institute of Washington

nept of Terregtrial Magnetian

5241 Broad Branch Road, N. W.

Washington 15, D. C.

Attn: Library

Georgia Tech Research Institute

$225 \mathrm{~N}$. Avenue, N. W.

Attn: Dr. James E. Boyd

Atlanta, Georgla

University of Marylani

College Park, Maryland

Attn: Dr. A. Weingtein

Ingtitute of Fluid Dynamics

Massachusetts Institute of Technologv

Lincoln Laboratory

P. ก. Box 73

Lexington 73, Magaachusetts

Attn: Prof. Radford, DIvigion 3 Hear

Wllow Run Regearch Center

Ent vergity of Michigan

willow Run Airport

Ypallant1, Michiean

Attn: Dr. C. L. Dolph

School or Eng 1 nearing

New York Uhi versity

Hnivergity Heights

New York, New York

Shell Fellowship Comittee of the

Shell Compantes Foundation, Inc.

50 West $50 t h$ Street

New York 20, N. Y.

Attn: Mr. J. R. Jansgen

Esso Research and Engineerting Co.

P. ก. Box 51

Linden, New Jersey

Attn: Mr. C. L. Brown, Manager

Union Carbide and Carbon Corp.

30 E. L2nd Street

Now York 17, New York

Attn: Mr. L. E. Erlanigon

Convatr

San Diego 12, California

Attn: Mr. Marvin Stern

Bell Telephone Laba., Inc.

1,63 west Street

New York 13, N. Y.

Attn: Dr. Mervin d. Kelly

Engineoring Library

Untversity of Californs

405 H1gard Avenue

Los Angeles 24, California
Conva1s, A D1v. of General Iymamicg Corp.

Fort. Worth 1, Texas

Attn: F. W. Cavia, Chief Engineer

Convalr. A D1v. of Genera] Symamics Corp.

Pomone, California

Attn: C. P. Parrine Ass't Div. Manater, Engin.

Shell Development Comany

Exploration and Froduction Res. D $v$. 3737 Bolla1re Boulevard

Houston 25, Texas

Attn: Miss Aphrodite Mam uli tes

RCA Lahoratories

Frinceton, New Jorsey

Attn: Dr. Charles Folk

Stanford Pesearch Instituto

S. Pasadena, Caljforria

Attn: Dr. J. Brandstatten

Nave State University

Kresge-Hooker Science Library

5250 Second Boulevaru

Detrott 2, Michigan

$A R P A$

1 Eond Street

Westbury, L. I., New York

Attn: Dr. Noman Spector

Varian Associates

(11 Hansen Way

Falo Alto, California

Attn: Mra. Perry Conway

$$
\text { Technical Librarian }
$$

Case Ingtitute of Technology

Department of Electrical Enin.

tniversity Gircle

Cleveland 6 , onto

Attn: Prof. Robert Plonsey

Dr. Ming S. Wong, CRPKP

Air Force Cambridge Research Center

Laurence G. Hanscom Fipld

Pedford, Massachusetts

Phystes Section

AVCN-RAD DIva1on

20 South Inion Street

Lawrence, Mass.

Attn: Dr. Ernest Bawer

Advanced Development Section

western Develcpment Labs.

Philco Corp.

3875 Fabian way

Palo Alto, Californds

Attn: Dr. Albert R. Giddis

Department of Aeronautical Engineerine

iniversity of Michipan

Ann Arbor, Michigan

Attn: Pror. Mahtnder toorol

Gordon Mclay Laboratory

Harvart tniversity

Cambridge 39, Mass.

Attr: Dr. S. R. Seshadr1

Commander

A1r Research and Development Command

Attn: ROTR

Andrews Alr Force Pase

vashinet on 25, D. C.

Convair, A Diviaion of General Dynantes Corp. Collfge of Engineering

Attn: J. E. Arnold, Division Manager

Dept. of Electrical Engi

infversity of Florida

Gainesville, Florida

Convair, A Diviston of Ceneral Dvnanics Corp. Attn: Dr. Sullivan

San Dlego 12, Cal1fornia

Attn: R. L. Bayless, Chief Englneer Dr. V. M. Fapadopoulos

Convalr, a Division of General Dynamics Corp. Frown University

San Diego 12, California

Attn: K. J. Bossart, Chief Engineer-WS107A

Major Vernon Lee Dawion

RSDD-CML(MO)

Pedatone Arsenal

Huntsvilie, Alabama

(rruman Aircarft Engineering Corp.

South ruster fay Road

Pethpage, Lons Igland, V. Y.

Attn: Dr. Charies Nack.

AF nefice of Sclentific Research

washington $25,0, C$

Attn: Dr. Kar] Kanlan

liniversity of Galifornia

Fadiation Lahorator

F. C. Pox ROR

Livermore, California

At $n$ : Dr. Bernard A. Lippmann

Dapartment of Electrical Engineering

Case Inst 1tute of Technology

University circle

Cleveland t, Ohio

Attn: Frofessor Altert E. Collin

Antenna Lahoratory

Air Force Cambridge Rosearch Center

Laurence G. Hangcom Fleld

Bedford, Massachusetts

Attn: Mr. Ph1lip Blackstone

Lt. Mark J. Beran, CRRD

A1r Force Cambitige Research Center

Laurence G. Hanscom Fleld

Bedford, Nassachugetts

Mr. Fichart Mack, CRRD

Air Force Camhridge Research Center

Laurance G. Hanscom field

Bedford, Massachusetts

System Development Corporation 2500 Colorado Avenue

Santa Monira, Caljfornta

Attn: Lihrary 

NEW YORK UNIVERSITY

INSTITUTE OF MATHHAATICAL SCIENCES

LIBR,ARY

4 Wathington Phace, New York 3, N. Y

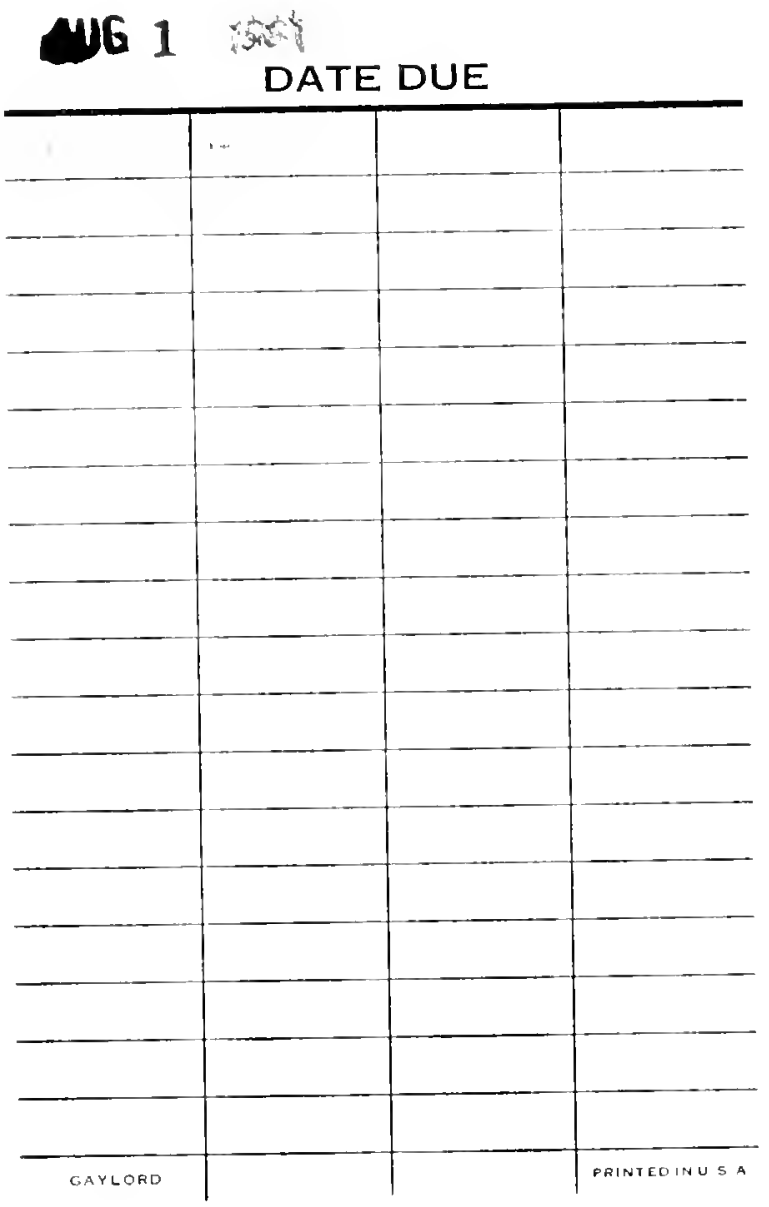




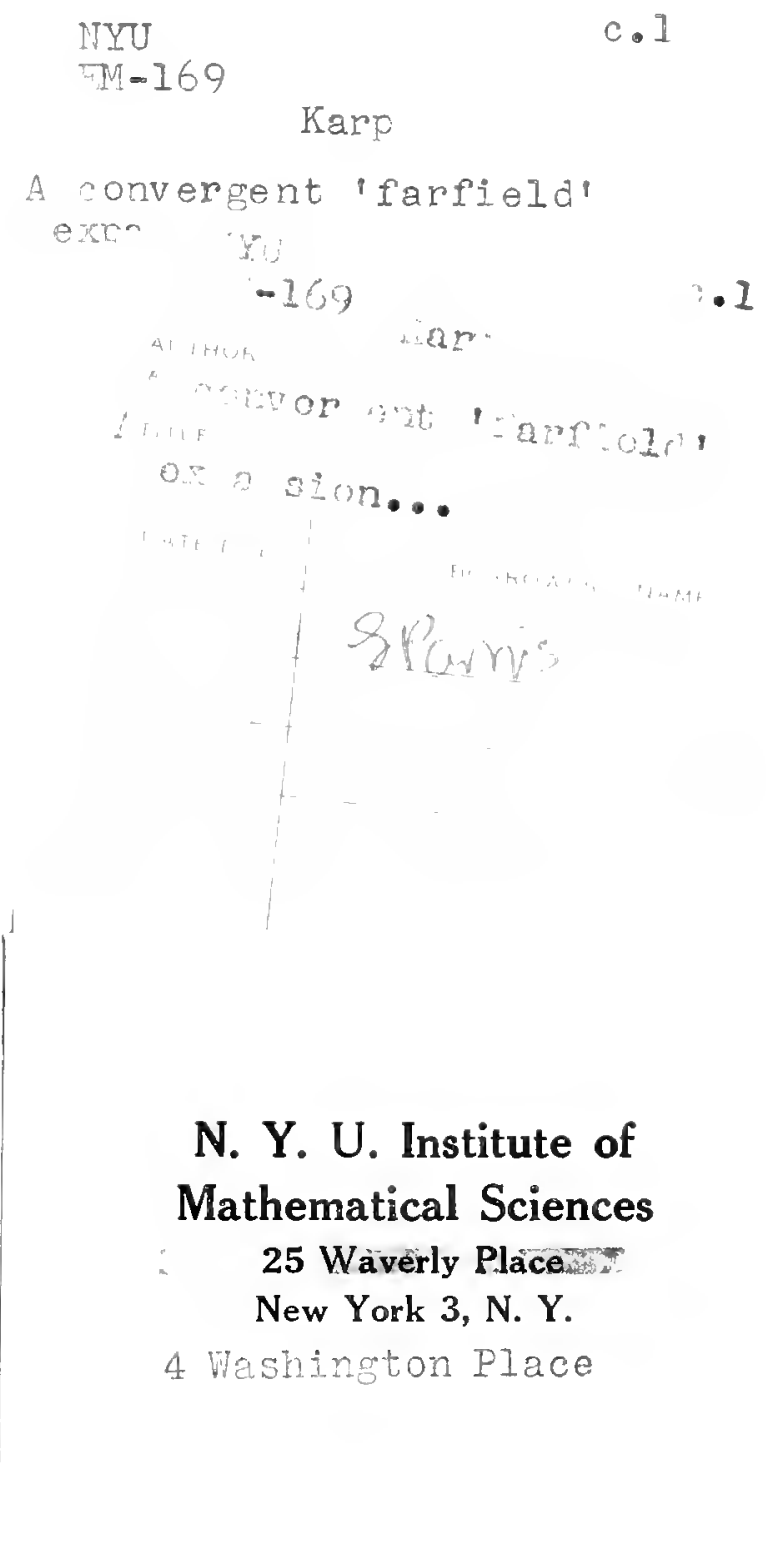


